Komunida: Media Komunikasi dan Dakwah

Volume 10 Nomor 01 2020; pp. 18-38; DOI: 10.35905/komunida.v7i2.

http://ejurnal.iainpare.ac.id/index.php/komunida/index

ISSN: 2088-0669: E ISSN: 26143704

\title{
KOMUNIKASI KELOMPOK DALAM VIRTUAL COMMUNITY
}

\section{Wa Ode Sitti Nurhaliza \\ Nurul Fauziah}

\begin{abstract}
This study aims to analyze communication in virtual communities that are reviewed from a business, health and career-linkedIn perspective. This research uses the literature review method through literature search both books and international and national journals. The results showed that the virtual community was established and developed through Computer Mediated Communication (CMC) on various platforms. Virtual communities develop because individuals have the same goal. They bind themselves to join and exchange ideas, information in a virtual community because there are common motives and goals to be achieved. There are several similarities and differences that bind individuals to join virtual communities from a business, health and career-linked perspective. Trust and security are the main keys of individuals joined in virtual communication in various fields. In addition, in the business perspective, two reasons individuals join online trade are the use of a conducive community and virtual social environment. While in the context of health, the reason the community joins is the ease of accessing health information, trust and security of user data. Finally, in the context of career-linked development, individuals tie themselves into the community because this platform has advantages in forming social network capital, knowledge capital to form friendships. Virtual communities on various platforms (business, health and careers) continue to grow and are increasingly being asked by users.
\end{abstract}

Keywords: community; social media; users; virtual

\begin{abstract}
Abstrak
Penelitian ini bertujuan untuk menganalisis komunikasi kelompok dalam virtual community (komunitas virtual) yang ditinjau dari perspektif bisnis, kesehatan dan pengembangan karir-linkedIn. Menggunakan metode literature review melalui pencarian literatur baik dari buku maupun jurnal-jurnal internasional dan nasional. Hasil penelitian menunjukkan bahwa Komunitas virtual terbentuk dan berkembang melalui Computer Mediated Communication (CMC) di berbagai platform. Komunitas virtual hadir dan berkembang yang dilatarbelakangi oleh indivdu-individu memiliki tujuan yang sama. Individu-individu yang mengikat dirinya untuk masuk dan bertukar gagasan, informasi dalam komunitas virtual dikarenakan ada persamaan motif dan tujuan yang hendak dicapai. Beberapa persamaan dan perbedaan ditemui yang mengikat individu-individu untuk bergabung dalam komunitas virtual ditinjau dari perspektif bisnis, kesehatan dan pengembangan karir-linkedIn. Kepercayaan dan
\end{abstract}

Komunikasi Kelompok dalam Virtual Community

Wa Ode Sitti Nurhaliza; Nurul Fauziah 
Komunida: Media Komunikasi dan Dakwah

Volume 10 Nomor 01 2020; pp. 18-38; DOI: 10.35905/komunida.v7i2.

http://ejurnal.iainpare.ac.id/index.php/komunida/index

ISSN: 2088-0669; E ISSN: 26143704

keamanan merupakan kunci utama individu tergabung dalam komunikasi virtual diberbagai bidang. Selain itu, dalam perpektif bisnis, kegunaan komunitas, lingkungan sosial virtual yang kondusif menjadi faktor individu tergabung dalam perdangangan online. Selanjutnya konteks kesehatan, kemudahan dalam mengakses informasi kesehatan selain kepercayaan dan keamanan data pengguna menjadi dasar orang tertarik masuk dalam komunitas. Terakhir, konteks pengembangan karirlinkedIn, individu mengikat diri masuk dalam komunitas dikarenakan platform ini memiliki kelebihan dalam membentuk modal jaringan sosial, modal pengentahuan hingga membentuk ikatan pertemanan. Komunitas virtual dalam berbagai platform tersebut (bisnis, kesehatan dan karir) terus berkembang dan semakin banyak dimintai oleh pengguna.

Kata Kunci: komunitas; media sosial; pengguna; virtual

\section{PENDAHULUAN}

Istilah media sosial populer pertama kali digunakan sekitar tahun 1994 (Baym, 2015) . Sejak awal kemunculan media sosial mempemudah masyarakat dalam mengakses berbagai informasi seperti pendidikan, politik, hiburan dan sebagainya. Berbagai ahli merumuskan definisi media sosial untuk memperkokok kajian media sosial dalam berbagai perspektif ilmu sosial khusunya komunikasi. Menurut Hunsinger dan Sentf (2014) menjelaskan media sosial berarti sebuah layanan informasi berjejaring yang dirancang untuk mendukung dalam interaksi sosial, pembentukan komunitas, peluang kolaboratif dan kejasama (Fuchs, 2014). Sedangkan menurut Shirky (2008), media sosial dan perangkat lunak sosial merupakan alat yang meningkatkan kemampuan pengguna untuk berbagai (to share), bekerjasama (to co-operate) di antara pengguna dan melakukan tindakan secara kolektif yang semuanya berada di luar kerangka institusional maupun organisasi (Nasrullah, 2016).

Berdasarkan kedua pengertian di atas, dapat dipahami bahwa media sosial merupakan media (alat/wadah) di internet yang memungkinkan individu-individu berkomunikasi, bertukar informasi bahkan bekerjasama dalam ruang publik virtual yang membentuk ikatan sosial secara virtual. Kemampuan media sosial juga terbukti

Komunikasi Kelompok dalam Virtual Community

Wa Ode Sitti Nurhaliza; Nurul Fauziah 
Komunida: Media Komunikasi dan Dakwah

Volume 10 Nomor 01 2020; pp. 18-38; DOI: 10.35905/komunida.v7i2.

http://ejurnal.iainpare.ac.id/index.php/komunida/index

ISSN: 2088-0669; E ISSN: 26143704

menjangkau berbagai hal termasuk membuka peluang dalam menjalin pertemanan secara virtual. Hal ini meungkinka(Li, 2014)n munculnya jaringan-jaringan pertemanan hingga membentuk berbagai kelompok komunikasi dalam dunia virtual atau yang disebut dengan virtual community.

Pemahamn tentang virtual community telah menuangkan berbagai pemikiran dikalangan ahli. Ada yang membedakan virtual community sebagai sebuah elemen penting yang di dalamnya mengandung ikatan dan budaya, bahkan ada yang beranggapan virtual community muncul dan berkembang dalam media komunikasi elektronik. Sebelum melihat pandangan virtual community dari beberapa ahli, Ling (2004) membedakan tiga jenis komunitas, yakni (1) komunitas berdasakran kekerabatan, (2) komunitas lokalitas, dan (3) komunitas pikiran. Ketiga tipe komunitas ini karena menyerupai komunitas yang dibentuk di internet (Li, 2014). Sebuah kelompok dikatakan komunitas ketika orang-orang di dalamnya menjalin komunikasi dan intrekasi yang memiliki kesamaan, menggunakan kode atau simbol sama yang hanya dipahami oleh komunitas itu sendiri.

Pendefinisian virtual community telah diungkapkan beberapa ahli diantaranya, Rothaermel dan Sugiyima (2001) berpendapat bahwa "komunitas virtual sama dengan komunitas yang memiliki satu pemikiran seperti yang dijelaskan Tonnies (1967), kecuali ia terbentuk melalui media komunikasi elektronik dan tidak terikat ruang dan waktu. Sementara menurut Bagozzi dan Dholakia, mendefinisikan virtual community sebagai: ruang sosial yang dimediasi dalam lingkungan digital yang memungkinkan sebuah kelompok untuk membentuk dan mempertahankan sesuatu melalui proses komunikasi yang berkesinambungan. Hal ini ditambahkan oleh Etzioni (1999), yang mendefinisikan virtual community sebagai komunitas yang memiliki dua elemen penting, yakni ikatan dan budaya (Li, 2014) .Berdasarkan uraian di atas dapat dipahami bahwa virtual community merupakan individu-individu

Komunikasi Kelompok dalam Virtual Community

Wa Ode Sitti Nurhaliza; Nurul Fauziah 
Komunida: Media Komunikasi dan Dakwah

Volume 10 Nomor 01 2020; pp. 18-38; DOI: 10.35905/komunida.v7i2.

http://ejurnal.iainpare.ac.id/index.php/komunida/index

ISSN: 2088-0669; E ISSN: 26143704

yang terlibat secara bersama, kesamaan pikiran, daya tarik yang membentuk ruang sosial dilingkungan digital sehingga membentuk satu ikatan dan budaya.

Dalam media sosial setiap individu selalu terlibat dalam virtual community. Ini menggarisbawahi bahwa manusia (agen/individu) adalah makhluk yang memiliki naluri untuk selalu bersama dan menjalin intrekasi dengan individu lainnya. Jika individu tidak dapat menggunakan satu bentuk komunikasi untuk terhubung secara efektif, individu akan menemukan yang lain, karena komunikasi dengan orang lain adalah hal mendasar bagi siapa dan bagaimana kita sebagai manusia (Picard, 2015). Hal ini pun tidak hanya terjadi dalam masyarakat nyata, akan tetapi hidup dan berkembang dalam masyarakat maya yang membentuk virtual community. Inidviduindividu ini menjaring, membangun bahkan memelihara ikatan kekeluargaan, pertemanan di media sosial. Melalui hubungan tersebut setiap individu mengekspresikan pikiran, gagasan, perasaan dan pendapat mereka. Bahkan dalam komunitasnya setiap individu bersedia berbagai pengamatan, pengalaman dan interpretasi tentang dunianya.

Interaksi sosial merupakan kebutuhan primer setiap manusia yang tidak hanya dalam dunia nyata tetapi terjadi juga dalam dunia maya. Bahkan intensitas komunikasi dalam ruang publik virtual terbilang cukup eksis. Data yang diperoleh dari UNESCO tahun 2018 bahwa masyarakat sangat aktif menggunakan media sosial. Ini ditunjukkan melalui penelitian UNESCO yang menunjukkan 4 dari 10 orang Indonesia sangat aktif menggunakan media sosial (Facebook 3,3 juta penggunna, WhatsApp 2,9 juta pengguna) https://kominfo.go.id/content/detail/14136/angkapenggunaan-media-sosial-orang-indonesia-tinggi-potensi-konflik-juga-amat-

besar/0/sorotan media (diakses 15 februari 2019). Tidak hanya media sosial, dalam berbagai perspektif lainnya seperti situs berbelanja online turut menjadi platform yang banyak diminati oleh penggunanya.

Komunikasi Kelompok dalam Virtual Community

Wa Ode Sitti Nurhaliza; Nurul Fauziah 
Komunida: Media Komunikasi dan Dakwah

Volume 10 Nomor 01 2020; pp. 18-38; DOI: 10.35905/komunida.v7i2.

http://ejurnal.iainpare.ac.id/index.php/komunida/index

ISSN: 2088-0669; E ISSN: 26143704

Perkembangan virtual community sebagai media komunikasi kelompok di dunia maya terbentuk dari berbagai motif mulai dari minat, pekerjaan, keterampilan, hobi, kelompok belajar, sumber informasi dan sebagainya. Adanya keseragaman minat menjadi faktor pendorong individu-individu membentuk kelompok virtual yang bertujuan untuk mengembangan informasi, pengetahun dan mobilitas bersama. Bahkan dalam setiap individu dapat memiliki beberapa virtual community diberbagai paltform. Hal ini tergantung pada minat masing-masing individu tersebut.

Perbedaan minat pada setiap individu juga menuntun dalam perbedaan cara berkomunikasi di setiap virtual community individu bergabung. Hal ini tanpa disadari terus terjadi dan berkembang secara kontinyu dan konsisten dilakukan oleh individuindividu yang membentuk virtual community di berbagai platform. Perilaku komunikasi dan pola interkasi individu disetiap virtual community-nya bisa berbeda tergantung pada situasi dan kondisi anggota yang berada dalam komunitas maya tersebut. Bahkan individu memberikan perlakukan berbeda terhadap komunitas maya dimana ia bergabung. Hal ini menunjukkan bahwa perilaku individu dalam virtual community memiliki varian atau kategori tertentu tergantung pada kebutuhan dan kedekatan inidvidu yang tergabung dalam group tersebut. Ditambah lagi nilai-nilai yang didapat dari dunia nyata juga dimasukan kedalam dunia virtual, begitupun sebaliknya.

Virtual community semakin berkembang dalam berbagai perspektif. Perdagangan online semakin menjamur turut memberi sumbangan dalam terbentuk komunitas virtual. Tidak hanya itu, bidang kesehatan bahkan pengembangan karier turut eksis memberikan kontribusi dalam komunitas virtual. Bebagai informasi dan layanan virtual disajikan yang menarik minat individu untuk bergabung. Penelitian ini fokus pada fenomena virtual community yang ditinjau dari perspektif bisnis, kesehatan dan pengembangan karier-linkedIn. Melalui riset ini, akan di uraikan apa saja yang menjadi alasan orang tergabung dalam komunitas virtual, bagaimana orang

Komunikasi Kelompok dalam Virtual Community

Wa Ode Sitti Nurhaliza; Nurul Fauziah 
Komunida: Media Komunikasi dan Dakwah

Volume 10 Nomor 01 2020; pp. 18-38; DOI: 10.35905/komunida.v7i2.

http://ejurnal.iainpare.ac.id/index.php/komunida/index

ISSN: 2088-0669; E ISSN: 26143704

merasa terikat, masuk dan bertahan ke dalam virtual community khususnya dalam bidang bisnis, kesehatan dan pengembangan karier melalui platform linkedIn.

Penelitian ini adalah penelitian fundamental menggunakan metode literature review. Sebuah pencarian literatur baik dari buku maupun jurnal-jurnal internasional dan nasional. Menggunakan literature review merupakan cara untuk mengembangkan argument penelitian terkait apa saja yang terjadi dialam komunitas virtual di media sosial. Proses litertur review yang dilakukan penelitian dengan mengumpulkan berbagai jurnal/artikel dan ebook yang berkaitan dengan topik penelitian. Penelitian ini lebih banyak menggunakan naratif review yang bertujuan untuk memperkaya pengetahuan terkait topik penelitian dengan menghasilkan pemahaman-pemahaman baru melalui pengetahuan. Dalam litertaure review hasil yang diperoleh bergantung pada hasil bacaan dari berbagai sumber yakni buku, jurnal maupun laporan-laporan sebelumnya yang tentu berkaitan dengan topik riset yang sedang dilakukan.

\section{PEMBAHASAN}

Media sosial menggambarkan jenis aplikasi World Wide Web $(W W W)$, seperti blog, microblog seperti Twitter, situs jejaring sosial, atau video/gambar/file berbagai platform (Fuchs, 2014). Karakteristik media sosial terdiri dari beberapa aspek yakni (1) partisipan, artinya orang-orang yang memiliki ketertarikan dalam bertukar informasi sehingga tidak ada batasan diantara audience di media sosial. (2) keterbukaan, penggunaan media sosial sangat terbuka untuk siapa saja yang ingin berkontribusi dan melakukan umpan balik. Orang-orang yang menggunakan media sosial mudah dalam berbagai informasi dan memberi komentar terkait hal-hal yang dimintainya. Selanjutnya (3) percakapan, media sosial mempermudah orang-orang dalam melakukan komunikasi dua arah dengan mudah dan cepat. (4) masyarakat, media sosial sangat memungkinkan membentuk masyarakat baru (online) dengan cepat dan bekomunikasi secara efektktif. Masyarakat dengan minat dan ketertarikan yang sama dengan mudah membentuk komunitas di media sosial. Terakhir (5) 
Komunida: Media Komunikasi dan Dakwah

Volume 10 Nomor 01 2020; pp. 18-38; DOI: 10.35905/komunida.v7i2.

http://ejurnal.iainpare.ac.id/index.php/komunida/index

ISSN: 2088-0669; E ISSN: 26143704

keterhubungan, media sosial berkembang pesat dalam ketehubungannya, dapat memanfaatkan berbagai situs, sumber saya dan individu lain (Mayfield, 2018). Melalui media sosial pengguna menjalin komunikasi yang juga membentuk komunitas.

Komunitas atau yang tampak sebagai komunitas terus berkembang melalui komunikasi yang dimediasi oleh komputer (Computer Mediated Communication$C M C$ ), seperti surat elektronik (email), ruang obrolan interkatif, konferensi melalui komputer dan sebagainya. $C M C$ adalah istilah umum yang merujuk pada komunikasi manusia melalui komputer. Terdapat dua jenis $C M C$ yakni $C M C$ sinkron (interkasi yang terjadi secara real time), dan $C M C$ asinkron, dimana peserta tidak harus online bersamaaan. CMC sinkron termasuk jenis obrolan online berbasis teks, computer, audio dan konferensi video, sedangkan asinkron $C M C$ meliputi email, forum diskusi dan sebagainya (Simpson, 2002). Salah satu hal potensial yang muncul dari komunitas virtual adalah munculnya hubungan virtual baru yang terjalin dikarenakan adanya kesamaan minat, hobi, tujuan dan sebagainya. Orang-orang tergabung dalam komunitas berdampak pada mengurangnya komunitas-komunitas Face to Face $(F T F)$. Komunikasi dalam komunitas virtual membentuk sebuah jaringan, norma, dan kepercayaan yang dibangun oleh orang-orang yang secara tidak sengaja bertemu dan berkumpul dalam satu platform. Jaringan umumnya didefinisikan sebagai jenis hubungan spesifik yang menghubungkan orang, objek, atau peristiwa yang telah ditentukan (Blanchard \& Horan, 2015). Hal ini merujuk pada jaringan dalam sebuah komunitas.

Komunitas yang terjalin melalui $C M C$ merupakan partisipasi dari kelompokkelompok yang tergolong dalam beberapa topik tertentu seperti kelompok latihan, kelompok kesehatan, kelompok bisnis bahkan kelompok pengembangan karier. Pertukaran informasi dalam kelompok virtual tentu mengurangi aktivitas fisik seperti halnya dalam komunitas didunia nyata. Hal inilah yang menjadi berbeda antara

Komunikasi Kelompok dalam Virtual Community

Wa Ode Sitti Nurhaliza; Nurul Fauziah 
komunitas virtual dan komunitas nyata. Komunitas nyata merupakan sekelompok orang yang memiliki hobi, minat yang sama bergabung menjadi satu dan melakukan berbagai aktivitas sfisik seperti bernyata, bermain bowling dan sebagainya. Sedangkan komunitas virtual adalah kumpulan dari beberapa individu yang tergabung karena memiliki ketertarikan yang sama dan terjalin melalui jaringan media sosial dalam beberapa platform.

Jaringan komunikasi yang terjalin dalam berbagai platform memiliki kemampuan untuk menemukan orang lain yang memiliki minat yang sama dan membentuk komunitas virtual. (Othmani \& Bouslama, 2015b) menjelaskan komunitas virtual sebagai platform elektronik yang menyediakan media bagi orangorang (belum saling kenal) yang memiliki minat yang sama dan berinterkasi, komunitas virtual juga dianggap sebagai sumber informasi baru dan komunikasi media baru antara orang atau bahkan perusahaan/organisasi. Studi komunitas virtual merupakan konsep yang cukup kompleks dikarenakan melibatkan multi aspek, multi faktor yang cukup luas. Beberapa ahli mengemukakan komunitas virtual berdasarkan pandangannya. Pertama, istilah "komunitas virtual" didefinisikan sebagai agregasi yang muncul di dunia maya ketika beberapa individu tergabung dalam kelompok untuk melakukan diskusi, berbagai informasi, perasaan yang membentuk jaringan hubungan pribadi (Rheingold, 2005) Kedua, Fernback dan Thompson (1995) mendefinisikan komunitas virtual sebagai sbeuah hubungan sosial virtual yang terjadi di dunia maya melalui kontak/komunikasi secara berulang tanpa batas dan membentuk komunitas yang memiliki minta pada topik yang sama. Sementara menurut Balasubramanian dan Mahajan (2001), komunitas virtual berhubungan dengan dunia maya yang memungkinkan orang-orang berinterkasi di dalamnya. Lebih lanjut Komunitas virtual sebagai sekelompok individu atau mitra bisnis yang berinteraksi bersama dan memiliki kepentingan yang sama secara elektronik (Othmani \& Bouslama, 2015a). Berbagai komunitas virtual yang ada membentuk 
Komunida: Media Komunikasi dan Dakwah

Volume 10 Nomor 01 2020; pp. 18-38; DOI: 10.35905/komunida.v7i2.

http://ejurnal.iainpare.ac.id/index.php/komunida/index

ISSN: 2088-0669; E ISSN: 26143704

ikatan sosial baru dan dipakai untuk memenuhi akan kebutuhan informasi yang sedang dicari. Individu yang tergabung dalam komunitas virtual tidak mengenal usia, jenis kelamin, latar belakang pendidikan, daerah asal dan sebagainya yang terbentuk secara random. Sebab, alasan individu tergabung dalam komunitas virtual adalah karena memiliki minat, hobi dan tujuan yang sama. Hal inilah yang menarik perhatian peneliti untuk mengkaji lebih dalam fenomena virtual community.

Dalam komunitas virtual, informasi merupakan "tindakan" utama yang dipertukarakan (Blanchard \& Horan, 2015). Anggota komunitas mengajukan pertanyaan yang kemudian anggota lainnya memberikan jawaban/infomasi kepada seluruh anggota kelompok. Bahkan terkadang, anggota kelompok menyebarkan informasi yang tidak diminta oleh anggota kelompok lainnya. Dukungan timbal baik adalah bagian vital dari komunitas virtual. Ditambah lagi, dalam memberikan bantuan tidak membutuhkan biaya besar karena semua dilakukan ketika antar anggota komunitas virtual terkoneksi dengan jaringan internet.

Kehadiran komunitas virtual membawa perubahan terhadap perilaku pengguna. Hal ini berkaitan pula ditandai munculnya berbagai platform yang menyediakan kebutuhan pengguna. Berbagai platform tersebut tidak hanya menyediakan infomasi, tetapi juga membentuk komunitas virtual sehingga para pengguna dapat memilih untuk bergabung ke komunitas manapun berdasarkan kebutuhan dan tujuannya. Beberapa platform yang tersedia menumbuhkan minat masyarakat untuk tergabung didalamnya dan menjadi sebuat komunitas virtual, diantarnya kehadiran komunitas virtual dalam bidang bisnis, kesehatan dan pengembangan karier-linkedIn.

\section{Komunitas Virtual: Perspektif Bisnis}

Perdangan online semakin pesat yang turut menghadirkan berbagai komunitas baru tentu memengaruhi perilaku pengguna berdasarkan pengalamannya. Hal ini

Komunikasi Kelompok dalam Virtual Community

Wa Ode Sitti Nurhaliza; Nurul Fauziah 
Komunida: Media Komunikasi dan Dakwah

Volume 10 Nomor 01 2020; pp. 18-38; DOI: 10.35905/komunida.v7i2.

http://ejurnal.iainpare.ac.id/index.php/komunida/index

ISSN: 2088-0669; E ISSN: 26143704

tentu menjadi keuntungan bagi perusahaan dalam meningkatkan penjualan melalui komunitas virtual. Komunitas virtual adalah sarana komunikasi komersial baru bagi perusahaan untuk berinteraksi dengan pelanggan yang terhubung (Othmani \& Bouslama, 2015b). Perdagangan online seperti bukalapak, lazada, shoppe dan sebagainya telah berhasil melahirkan komunitas virtual dimasyarakat Indonesia. Beragam jenis pebisnis online membuat banyak perusahaan online yang berusahan meyakinkan pelanggan dan mendapatkan kepercayaan dari pelanggan. Dalam hal ini kepercayaan merupakan unsur penting dalam meningkatkan manajemen hubungan pelanggan.

Menurut (R.Roy, 2012) menjelaskan kepercayaan merupakan elemen penting dalam upaya kolaboratis Virtual Community Team (VTC). Dalam konteks bisnis, kepercayaan pelanggan terhadap pebisnis online merupakan kunci dasar dalam menarik minat pelanggan. Para pelanggan yang memiliki minat yang sama tergabung kedalam komunitas virtual dan satu sama lain dapat saling berkomentar dan membagikan postingan yang sama terkait produk yang digemari. Bahkan kepercayaan online dapat meningkatkan niat beli dan memberikan persepsi politik terhadap satu produk atau perusahaan tertentu. Kepercayaan konsumen didasari pada pengalaman (apakah pernah membeli barang tersebut atau informasi dari orang ke orang) tetapi tidak terbatas pada budaya, sosial dan ekonomi. Hubungan ini menjadi mudah diakses melalui kehadiran komunitas virtual yang didalamnya setiap individu dapat berbagi pengetahun, pertukaran informasi dan pengambangan empati dalam komunitas.

Individu tertarik untuk tergabung dalam komunitas virtual dalam konteks bisnis didasarkan pada beberapa hal yakni: pertama, manfaat yang diperoleh ketika terhubung dalam komunitas virtual. Hal ini merujuk pada kemampuan situs web dalam menyediakan berbagai produk dan layanan sesuai kebutuhan konsumen. Selain itu, hadirnya situs web memberi manfaat bagi konsumen yang dapat berbagi

Komunikasi Kelompok dalam Virtual Community

Wa Ode Sitti Nurhaliza; Nurul Fauziah 
Komunida: Media Komunikasi dan Dakwah Volume 10 Nomor 01 2020; pp. 18-38; DOI: 10.35905/komunida.v7i2. http://ejurnal.iainpare.ac.id/index.php/komunida/index

ISSN: 2088-0669: E ISSN: 26143704

informasi, komunikasi dan pengetahuan yang tentu memengaruhi tingkat kepercayaaan konsumsen terhdapa produk/pebisnis online. Sebagai contoh salah satu web penjualan online populer yang menyediakan beragam produk yakni Shoppe. Individu-individu yang tergabung dalam komunitas virtual yang kerap berbelanja di situs web shoppe memperoleh kegunaan berupa kualitas informasi produk yang ditampilkan tidak berbeda jauh produk aslinya. Kegunan lainnya yakni kemudahan dalam mengakses informasi, biaya murah, dapat dilakukan kapan dan dimana saja (tetap terkoneksi internet) dan proses pengiriman barang tergolong instan. Ini menjadi alasan kekuatan komunitas virtual dalam bidang bisnis memperoleh peluang besar bagi para pebisnis online. Hal ini sejalan dengan yang dikemukakan oleh (Othmani \& Bouslama, 2015b) bahwa kegunaan komunitas virtual dapat ditinjua dari nilai efektifitas perannya, relevansi infomasi yang dibagikan, kekuatan arus informasi dan pengetahuan.

Kedua, komunitas virtual turut menghadirkan lingkungan sosial virtual pula. Lingkungan sosial virtual memainkan peran penting dalam memengaruhi perilaku konsumen sebagai anggota komunitas virtual yang dilihat dari rekomendasi dan ulasan pada situ web. penujualan online. Setiap hari bahkan setiap jam jumlah anggota komunitas virtual terus bertambah yang memungkinkan sesama konsumen membagikan informasi berupa pengalaman dengan produk yang pernah diberi dan layanan yang diterima. Interkasi dan pertukaran pesan dalam komunitas virtual dapat memberikan informasi tambahan kepada konsumen yang membentuk persepsi pelanggan. Ditambah lagi, bebagai ulasan konsumen yang telah berkunjung menjadi informasi tambahan bagi komunitas virtual lainnya.

Terakhir, berkaitan dengan keamanan pengguna dalam komuniras virtual. Hal ini tentu sangat krusial dalam perdangangan online. Dalam konteks komunitas virtual, keamanan merujuk pada perlindungan informasi konsumen berupa nama, alamat email, kontak person dan sebagainya. Keamanan tentu memengaruhi kepercayaan 
Komunida: Media Komunikasi dan Dakwah

Volume 10 Nomor 01 2020; pp. 18-38; DOI: 10.35905/komunida.v7i2.

http://ejurnal.iainpare.ac.id/index.php/komunida/index

ISSN: 2088-0669; E ISSN: 26143704

konsumen tehadap jenis perdangan online. Untuk itu informasi komunitas virtual harus kredibel, dan juga konsisten dengan kebutuhan anggota komunitas yang tediri dari para konsumen.

Dengan demikian, komunitas virtual dalam konteks bisnis menawarkan hubungan simbiosis mutalisme (timbal balik) antara konsumsen dan pebisnis online. Ketika komunitas virtual dalam bidang bisnis ditingkatkan dengan teknologi kemanan yang tinggi, konten (pesan) yang relevan dan konteks yang sesuai tentu memengaruhi kepercayaan konsumen. Melalui kemanan yang tinggi, kenyamanan dan kemudahakan dalam mengakses informasi, komunitas virtual sebagai konsumsen dapat meningkatkan kepercayaannya terhadap web.situs belanja online.

\section{Komunitas Virtual: Perspektif E-Healt}

Perkembangan teknologi informasi dan komunikasi memengaruhi seluruh lini kehidupan, tak terkecuali bidang kesehatan. Di era digital yang serba cepat dan canggih terus berkembang dan berubah setiap waktu bahkan setiap detik. Ditambah lagi transisi masyarakat Indonesia menjadi masyarakat informasi. Hal ini mengacu pada kebutuhan informasi semakin tinggi, semakin bergantung pada inovasi teknologi yang terus berkmbang. Perubahan habit masyarakat ini membawa dampak pada ketersediaan informasi dari berbagai saluran.

Komunitas virtual terbentuk ketika beberapa individu tidak dapat bertemu secara face to face. Komunitas virtual juga muncul dalam berbagai konteks termasuk perawatan kesehatan (Kay \& Holmes, 2018). Berbagai platform berbasis pelayanan kesehatan saat ini mulai muncul dan berkembang. Hal ini tentu mempermudah pengguna dalam mengakses berbagai informasi kesehatan.Aplikasi jejaring media sosial telah mendapat popularitas yang tinggi karena secara bersamaa menyatukan pencari berbagai informasi kesehatan (pasien) dan penyedia saran pengobatan (dokter/institusi terbaik) (Aydin \& Perdahci, 2016). Di Indonesia, aplikasi jejaring 
Komunida: Media Komunikasi dan Dakwah Volume 10 Nomor 01 2020; pp. 18-38; DOI: 10.35905/komunida.v7i2. http://ejurnal.iainpare.ac.id/index.php/komunida/index

ISSN: 2088-0669: E ISSN: 26143704

sosial kesehatan atau yang dikenal dengan sebutan e-health mulai berkembang. Kementerian Kesehatan (Kemkes) meluncurkan informasi kesehatan platform pada bulan september 2018, yakni Sehatpedia. Menurut Kepala Sub Bagian Advokasi Hukum dan Humas Ditjen Yankes Kemenkes, Rico Mardiansyah mengatakan bahwa Adanya aplikasi Sehatpedia bertujuan untuk memperluas layanan kesehatan di era digital seperti sekarang ini, dikutip dari kompas.com., Kamis (11/10/2018). Lebih lanjuti dijelaskan bahwa pihak Kemenkes mengaharapkan aplikasi kesehatan dapat menjangkau masyarakat pelosok untuk bisa konsultasi, dan memberikan edukasi kepada masyarakat (Dewi, 2018).

Sedangkan wilayan Eropa juga memiliki salah satu jaringan kesehatan interaktif online terkemuka (www.doktorsitesi.com). Situs web.nya memiliki sekitar satu juta pengguna (pasien yang sama) dan 15.000 dokter. Situs web tersebut menyediakan berbagai fitur-fitur jejaring sosial seperti pesan pribadi, bertukar informasi melalui pertanyaan dan jawaban (Aydin \& Perdahci, 2016). Melalui web. kesehatan interaksi menarik terjadi antara orang-orang yang tergabung di dalamnya. Apabila dibandingkan dengan platform kesehatan di Indonesia, wilayah Eropa memiliki jumlah pengguna lebih tinggi.

Aplikasi Sehatpedia menyediakan empat menu utama yakni beranda, artikel, pandaftaran dan e-policy. Pengguna yang tergabung dalam platform ini diberi informasi terkait gejala penyakit, tips-tips kesehatan dan penjelasan (konsultasi) dengan dokter melalui online. Meskipun jumlah pengguna Sehatpedia Indonesia baru mencapai 10\% dari total penduduk Indonesia dan apliaksi pengguna kesehatan online berada di sisi barat Indonesia(Petriella, 2019). Sedangkan total dokter yang tergabung dalam platform ini adalah 582 dari 32 RS Veritikal. Namun pihak Kemenkes terus melakukan sosialisasi dan meyakinkan masyararat akan manfaat menggunakan $E$ healt.

Komunikasi Kelompok dalam Virtual Community

Wa Ode Sitti Nurhaliza; Nurul Fauziah 
Komunida: Media Komunikasi dan Dakwah Volume 10 Nomor 01 2020; pp. 18-38; DOI: 10.35905/komunida.v7i2.

http://ejurnal.iainpare.ac.id/index.php/komunida/index

ISSN: 2088-0669; E ISSN: 26143704

Keberadaan E-healt tentu menjadi ladang bisnis online berbasis kesehatan. Kemampuan dan kecanggihan web.yang digunakan meliputi kemudahan dalam mengakses, kecepatan informasi, kepercayaan hingga tingkat keamanan data pengguna menjadi unsur penting. Individu yang telah tergabung ataupun berniat bergabung dalam e-healt tentu memperhatikan unsur-unsur tersebut. Bahkan disemua platform yang mengundang munculnya komunitas virtual baru harus mempertimbangkan tingkat kemanan data pengguna sehingga dapat memeproleh kepercayaan dari user. Ketika keamanan dan kepercayaan telah ditingkatkan, maka akan berdampak pada jumlah individu yang tergabung dalam komunitas virtual semakin bertambah.

Komunitas virtual dalam bidang kesehatan mulai berkembang yang terjalin melalui jaringan komunikasi antara dokter dan pasien melalui sebuah platform (Sehatpedia). Meskipun komunitas virtual ini terbentuk tanpa disadari dan direncanakan, namun hal ini menunjukkan bahwa bidang kesehatan menjadi sasaran dalam terbentuknya masyarakat maya. Individu-individu yang tergabung dalam platform Sehatpedia secara tidak langsung menjadi sebuah komunitas virtual yang terhubung sebagai pencari dan penyedia informasi kesehatan.

\section{Komunitas Virtual : Perspektif Pengembangan Karier - LinkedIn}

Komunitas virtual mengacu pada sebuah kelompok yang memiliki kepentingan bersama. Ini didasarkan pada aspek pribadi dan sosial anggota kelompok virtual. Aspek pribadi meliputi kemampuan seseorang untuk membentuk identitas diri melalui postingan dan aspek sosial merujuk pada lingkungan individu yang di dalamnya terdiri dari orang-orang dengan minta atu identitas bersama yang disatukan untuk mencapai tujuan.

Kehadiran platform pengembangan karier-linkedIn menyediakan berbagai layanan kepada pengguna untuk terhubung satu sama lain yang didasarkan pada jenis

Komunikasi Kelompok dalam Virtual Community

Wa Ode Sitti Nurhaliza; Nurul Fauziah 
Komunida: Media Komunikasi dan Dakwah

Volume 10 Nomor 01 2020; pp. 18-38; DOI: 10.35905/komunida.v7i2.

http://ejurnal.iainpare.ac.id/index.php/komunida/index

ISSN: 2088-0669: E ISSN: 26143704

pekerjaaan, alumni sekolah, alumni perusahaan dan sebagainya. Bahkan linkedIn menawarkan pengguna untuk membuat profil sebagai promosi dalam mencari pekerjaan. Terdapat beberapa unsur yang mengikat individu untuk tergabung kedalam komunitas virtual yakni; modal jaringan sosial, modal pengetahuan dan persekutuan (menjaring ikatan). Ketiga komponen tersebut ditemukan pada komunitas yang tergabung dalam platform linkedIn (Rheingold, 2005).

Pertama; modal jaringan sosial; merujuk pada cara individu untuk menemukan orang lain dengan minat yang sama dalam komuniras virtual. Komunitras virtual menambah modal sosial yang melakukan kontak dengan orang-orang baru dan merasa bahwa mereka merasa semua orang didunia terhubung (Steinfield, Ellison, Lampe, \& Vitak, 2012) linkedIn membuat dunia lebih kecil. Melalui spacesyber, dapat meningkatkan komunikasi diantara orang-orang yang memiliki kepentingan yang sama dan yang berada dilokasi yang sama ataupun lokasi yang ebrbeda. Misalnya komunitas yang terjalin dengan orang-orang yang bekerja pada bidang yang sama, lingkungan perusahaan yang berbeda bahkan bekerja untuk perusahaan yang berbeda). Sesama pengguna dapat terhubung dan berkomunikasi meskipun tidak saling mengenal dalam platform linkedIn. Hal ini tentu mendorong orang-orang untuk berdiskusi dan bertukar pikiran tentang minat pekerjaan melalui situs blog dan forum diskusi (jawaban). Ini menungkinkan terjadinya koneksi professional dimana orangorang dapat mengajukan pertanyaan dan membuat keputusan yang tepat. Sehingga modal jaringan sosial yang terkonstruksi melalui komunitas virtual merupakan jaringan yang mampu menyediakan transparansi yang tidak bisa disediakan melalui ofline.

Kedua, modal pengetahuan. Platform linkedIn menyediakan beragam informasi untuk para pencari kerja dan dapat berinterkasi secara professional. LinkedIn menyasar pengguna bisnis professional. Platform ini menawarkan banyak fitur untuk membangun dan memelihara jaringan bisnis yang berfokus pada mendorong

Komunikasi Kelompok dalam Virtual Community

Wa Ode Sitti Nurhaliza; Nurul Fauziah 
Komunida: Media Komunikasi dan Dakwah Volume 10 Nomor 01 2020; pp. 18-38; DOI: 10.35905/komunida.v7i2. http://ejurnal.iainpare.ac.id/index.php/komunida/index

ISSN: 2088-0669: E ISSN: 26143704

hubungan professional (Al H.Al-badi, Okam, Roobaea, \& Mayhew, 2013). Hubungan professional yang dibangun melalui platform linkedIn seperti menemukan kolega/teman lama (berhubungan ekmabli dengan kolega dan rekanan), berselancar di pasar kerja melalui ruang cyberspace, dapat melakukan kontak dengan professional lainta untuk mempelajar atau memperoleh pengetahuna terkait topik tertentu. Untuk membangun hubungan professional, pengguna platform linkedIn tentu harus menyusun portofolio (yang berisi informasi pribadi yang manarik seperti pengalaman kerja, minat dan bakat dan sebagainya) untuk memenuhi target yang diinginkan. Melalui blog linkedIn pengguna dapat memperluas pengetahuan tentang berbagai topik. Misalnya, pengguna mencoba untuk memperoleh pengetahuan tentang pemasaran produk. Dapat menggunakan jajak pendapat dan semua orang yang terhubung dapat mengisi serta berkomentar untuk memberi jawaban. Hal ini efektf untuk memperoleh ide/pengetahuan yang baik terkait promosi suatu produk.

Ketiga, perkumpulan - menjaring ikatan pertemanan. Komunikasi menjadi sangat penting dalam interkasi komunitas. Komunitas online dapat membangun hubungan dengan orang-orang yang mungkin tidak dikenal atau tidak pernah bertemu dalam dunia nyata. Saat ini jumlah pengguna linkedIn mencapai 500 juta (https://tekno.kompas.com/read/2017/04/25/19310077/pengguna.linkedin.sudah.temb us.500.juta. (diakses 22 september 2019) yang memungkinkan pengguna untuk tergabung dan membangun hubungan bisnis baru ke dalam forum bisnis, alumni, industri, konferensi, klub penggemar dan sebagainya. Komunikasi yang terjalin melalui platform linkedIn dapat dimulai dengan memberikan pertanyaan kepada komunitas, mengomentari proyek dan memberi selamat kepada sesorang atas promosi jabatan yang diperoleh. Bahkan platform linkedIn, pengguna dapat memerika profil seseorang sebelum mengajukan pertanyaan ataupun berkomentar. Selain itu, pengguna dapat mengetahui siapa saja yang mengunjungi profil pribadinya.

Komunikasi Kelompok dalam Virtual Community

Wa Ode Sitti Nurhaliza; Nurul Fauziah 
Komunida: Media Komunikasi dan Dakwah

Volume 10 Nomor 01 2020; pp. 18-38; DOI: 10.35905/komunida.v7i2.

http://ejurnal.iainpare.ac.id/index.php/komunida/index

ISSN: 2088-0669; E ISSN: 26143704

Kemungkinan untuk menjaring pertemanan khususnya dalam konteks bisnis sangat mungkin terjadi melalui platform linkedIn.

Secara ringkas, terdapat beberapa persamaan dan perbedaan yang mengikat individu-individu untuk bergabung dalam komunitas virtual ditinjau dari perspektif bisnis, kesehatan dan pengembangan karier-linkedIn yang kemudian diringkas pada gambar berikut ini:

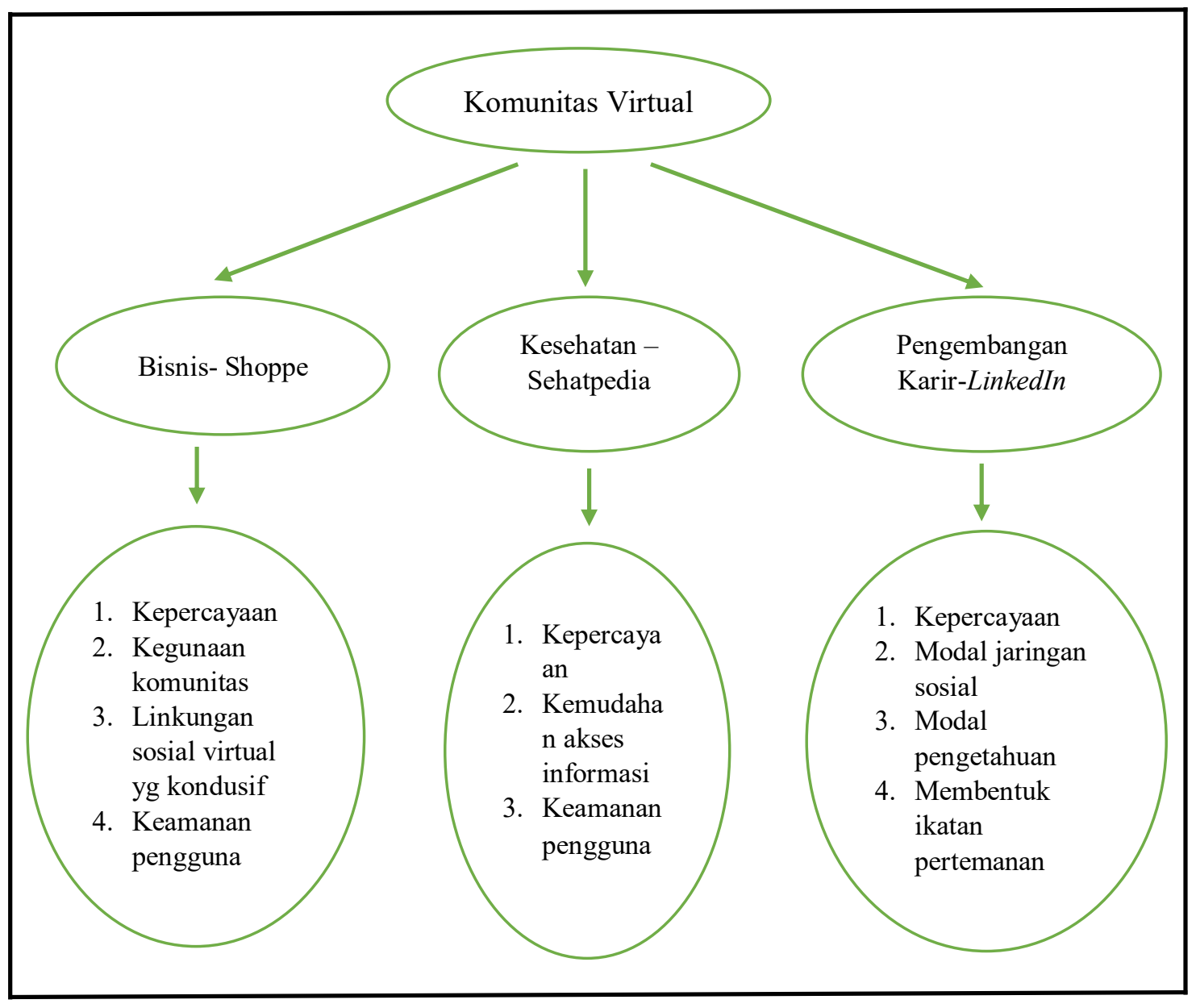

Sumber: Peneliti, 2019

Gambar 1 Komunikasi dalam Virtual Community: Perspektif Bisnis, Kesehatan \&Pengembangan Karier-linkedIn

Komunikasi Kelompok dalam Virtual Community

Wa Ode Sitti Nurhaliza; Nurul Fauziah 
Komunida: Media Komunikasi dan Dakwah

Volume 10 Nomor 01 2020; pp. 18-38; DOI: 10.35905/komunida.v7i2.

http://ejurnal.iainpare.ac.id/index.php/komunida/index

ISSN: 2088-0669; E ISSN: 26143704

Dengan demikian, komunitas virtual muncul dan berkembang melalui berbagai komunitas yang memiliki tujuan yang sama. Terbentuknya komunitas virtual di berbagai aspek (seperti bisnis, kesehatan dan pengembangan karier) menjadi bukti bahwa untuk menciptakan komunikasi yang efektif dan efisien tidak mesti melalui face to face. Melalui komunitas virtual yang terjaring melalui jaringan media sosial turut melahirkan lingkungan sosial virtual pula. Individu-individu yang mengikat dirinya untuk masuk dan bertukar gagasan, informasi dalam komunitas virtual dikarenakan ada persamaan motif dan tujuan yang hendak dicapai. Kepercayaan menjadi kunci utama orang-orang tergabung dalam komunitas virtual. Kualitas pesan yang dibagikan, kemudahan pengguna dalam men-share berbagai informasi dan keamanan data pengguna menjadi beberapa indikator yang menyebabkan orang-orang bertahan dalam komunitas virtual.

\section{SIMPULAN}

Komunitas virtual terbentuk dan berkembang melalui Computer Mediated Communication (CMC) di berbagai platform. Komunitas virtual hadir dan berkembang yang dilatarbelakangi oleh indivdu-individu memiliki tujuan yang sama. Individu-individu yang mengikat dirinya untuk masuk dan bertukar gagasan, informasi dalam komunitas virtual dikarenakan ada persamaan motif dan tujuan yang hendak dicapai. Beberapa persamaan dan perbedaan ditemui yang mengikat individuindividu untuk bergabung dalam komunitas virtual ditinjau dari perspektif bisnis, kesehatan dan pengembangan karier-linkedIn. Kepercayaan dan keamanan merupakan kunci utama inidvidu tergabung dalam komunikasi virtual diberbagai bidang. Selain itu, dalam perpektif bisnis, kegunaan komunitas, lingkungan sosial virtual yang kondusif menjadi faktor individu tergabung dalam perdangangan online. Selanjutnya konteks kesehatan, kemudahan dalam mengakses informasi kesehatan selain kepercayaan dan keamanan data pengguna menjadi dasar orang tertarik masuk dalam komunitas. Terakhir, konteks pengembangan karir-linkedIn, individu mengikat 
Komunida: Media Komunikasi dan Dakwah

Volume 10 Nomor 01 2020; pp. 18-38; DOI: 10.35905/komunida.v7i2.

http://ejurnal.iainpare.ac.id/index.php/komunida/index

ISSN: 2088-0669; E ISSN: 26143704

diri masuk dalam komunitas dikarenakan platform ini memiliki kelebihan dalam membentuk modal jarigan sosial, modal pengentahuan hingga membentuk ikatan pertemanan. Komunitas virtual dalam berbagai platform tersebut (bisnis, kesehatan dan karir) terus berkembang dan semakin banyak dimintai oleh pengguna. Peneliti selanjutnya dapat mengambangkan analisisnya yang berfokus pada berbagai varian komunikasi yang dipertukarkan dalam komunitas virtual. Selain itu, dalam konteks penelitian komunitas virtual, peneliti selanjutnya dapat mengembangkan pada bidang perbandingan komunikasi kelompok yang terjadi dalam kontek face to face dan melalui platform.

\section{DAFTAR PUSTAKA}

Al H.Al-badi, A. H., Okam, O., Roobaea, R. Al, \& Mayhew, P. J. (2013). Improving Usability of Social Networking Systems : A Case Study of LinkedIn. Journal If Internet Social Networking \& Virtual Communities, 2013, 1-23. https://doi.org/10.5171/2013.889433

Aydin, M. N., \& Perdahci, N. Z. (2016). Network Analysis of an Interactive Health Network. Journal Of Internet Social Networking \& Virtual Communities, 2016. https://doi.org/10.5171/2016.

Baym, N. K. (2015). Social Media and the Struggle for Society. Social Media and Society, April-JUli(Social Media and the Struggle fo Society), 1-2. https://doi.org/10.1177/2056305115580477

Blanchard, A., \& Horan, T. (2015). Virtual Communities and Social Capital (Vol. Chapter I). https://doi.org/10.1177/089443939801600306

Dewi, R. K. (2018). Sehatpedia, Aplikasi Konsultasi dan Layanan Kesehatan Buatan Kemenkes Halaman all - Kompas. Retrieved from https://lifestyle.kompas.com/read/2018/10/11/152635920/sehatpedia-aplikasikonsultasi-dan-layanan-kesehatan-buatan-kemenkes?page=all

Fuchs, C. (2014). Social Media a cricitcal intoduction. London: SAGE Publications, Ltd.

Kay, R. H., \& Holmes, J. M. (2018). Exploring Virtual Communities of Practice in Healthcare Education Exploring Virtual Communities of Practice in Healthcare Education. In EdMedia: World Conference on Educational Media and 
Komunida: Media Komunikasi dan Dakwah Volume 10 Nomor 01 2020; pp. 18-38; DOI: 10.35905/komunida.v7i2. http://ejurnal.iainpare.ac.id/index.php/komunida/index

ISSN: 2088-0669: E ISSN: 26143704

Technology (pp. 1686-1691). Amsterdam, Netherlands. Retrieved from https://www.researchgate.net/publication/328702854_Exploring_Virtual_Comm unities_of_Practice_in_Healthcare_Education

Li, H. (2014). Virtual Community Studies: A Literature Review, Synthesis and Research Agenda. Proceedings of the Americas Conference on Information Systems, New York, (January 2004).

Nasrullah, Rulli. 2016. Media Sosial (Perspektif Komunikasi, Budaya dan Sosioteknologi). Bandung. PT. Remaja Rosdakarya.

Othmani, L., \& Bouslama, N. (2015a). Perceived Quality of a Virtual Community and Its Components: An Exploratory Investigation. Journal of Internet Social Networking \& Virtual Communities, 2015. https://doi.org/10.5171/2015.

Othmani, L., \& Bouslama, P. N. (2015b). Highlighting the Influence of Virtual Communities on the Online Shopper Trust. Journal of Internet Social Networking \& Virtual Communities, 2015. https://doi.org/10.5171/2015.603496

Petriella, Y. (2019). Payung Hukum Aplikasi Kesehatan Online Mendesak - Ekonomi Bisnis. Retrieved from https://ekonomi.bisnis.com/read/20190820/12/1138705/payung-hukum-aplikasikesehatan-online-mendesak

Picard, R. G. (2015). The humanisation of media? Social media and the reformation of communication. Communication Research and Practice, 1(1), 32-41. https://doi.org/10.1080/22041451.2015.1042421

Putri, N. E., Hakim, N., \& Yamin, M. (2016). Ecologicall Footprint and Biocapacity Analysis for Flooding Prevention in South Sumatera. Jurnal Mimbar, 32(1), 5864.

R.Roy, S. (2012). Virtual Collaboration: The Skills Needed to Colaborate in a Virtual Enviroment. Journal Of Internet Social Networking \& Virtual Communities, 2012, 1-8. https://doi.org/10.5171/2012.629512

Rheingold, B. H. (2005). The Virtual Community: Table of Contents.

Simpson, J. (2002). Computer-mediated communication. Journal Volume 56/4. Oxford University Press., 56(October), 414-415.

Steinfield, C., Ellison, N., Lampe, C., \& Vitak, J. (2012). Online social network sites and the concept of social capital. In The Internet Turning 40 Conference School of Journalism and Mass Communication Chinese (pp. 115-131). New York: Routledge.

Retrieved

from

Komunikasi Kelompok dalam Virtual Community

Wa Ode Sitti Nurhaliza; Nurul Fauziah 
Komunida: Media Komunikasi dan Dakwah

Volume 10 Nomor 01 2020; pp. 18-38; DOI: 10.35905/komunida.v7i2.

http://ejurnal.iainpare.ac.id/index.php/komunida/index

ISSN: 2088-0669: E ISSN: 26143704

https://www.researchgate.net/publication/328702854_Exploring_Virtual_Comm unities_of_Practice_in_Healthcare_Education

\section{Sumber Lain:}

https://kominfo.go.id/content/detail/14136/angka-penggunaan-media-sosial-orangindonesia-tinggi-potensi-konflik-juga-amat-besar/0/sorotan_media (diakses 15 februari 2019).

(https://tekno.kompas.com/read/2017/04/25/19310077/pengguna.linkedin.sudah.temb us.500.juta. (diakses 22 september 2019)

Komunikasi Kelompok dalam Virtual Community

Wa Ode Sitti Nurhaliza; Nurul Fauziah 